\title{
Assessment of Drainage Water Quality in Siwa Oasis and Its Suitability for Reuse in Agricultural Irrigation
}

\author{
Ramzy M. R. Hedia
}

Soil and Water Science Department, Faculty of Agriculture, Alexandria University, Egypt.

\begin{abstract}
NE of the most challenges to increase water resources use efficiency and sustainability in arid and semiarid regions is the reuse of drainage water. The objective of this study was to assess the quality of drainage water in Siwa oasis and to address the suitability of its reuse to serve the sustainable management of water resources in the oasis. Georeferenced drainage water samples were collected in triplicates from 182 drains distributed around the oasis having different categories indicated by their depths ranging from 0.5 to 2.65 m. Measurements of $\mathrm{pH}, \mathrm{EC}$ and analyses for soluble $\mathrm{Na}^{+}, \mathrm{Ca}^{2+}, \mathrm{Mg}^{2+}$ and $\mathrm{Cl}^{-}$ions and $\mathrm{NO}_{3}-\mathrm{N}$ were conducted then SAR and RSC were calculated. Volumes of drainage water were calculated using measured wetted length, width and depth of the sampled drains segments. Descriptive statistics, frequency distribution and Piper tri-linear analyses were performed on the obtained data. The calculated volume weighted averages of $\mathrm{pH}_{\mathrm{avg}}, \mathrm{EC}_{\mathrm{avg}}, \mathrm{SAR}_{\mathrm{avg}}, \mathrm{RSC}_{\mathrm{avg}}$, and $\mathrm{NO}_{3}-\mathrm{N}_{\mathrm{avg}}$ were $8.85 \mathrm{dS} / \mathrm{m}, 7.46,21.19,1.72$ and $13.51 \mathrm{mg} / \mathrm{l}$, respectively. These averages were found to be generally higher than their calculated mathematical mean values. This represents C3S4 class of salinity and sodicity hazards and nitrate has not any impact on the environment. Application of the Piper tri-linear diagram for the hydrochemical facies indicated that drainage water is $\mathrm{Na}-\mathrm{Cl}-\mathrm{SO}_{4}$ type. For such an isolated oasis, regulation of groundwater pumping, lining irrigation canals and improvement of drainage networks, application of modern irrigation systems, the adoption of a suitable IFDM system and increasing the public awareness of the water crisis were suggested by the author.
\end{abstract}

Keywords: Drainage water, Water quality, Salinity/sodicity hazards, Hydrochemical facies.

In areas where irrigation water is scarce, the reuse of drainage water is an important strategy for supplementing water resources. Furthermore, reuse may help alleviate drainage disposal problems by reducing the volume of drainage water involved. The reuse of drainage water for irrigation can reduce the overall problems of water pollution (Tanji and Kielen, 2002). Water quality assessment and understanding the factors affecting this quality are very important baselines from which effective management and sustainable development of water resources could be properly achieved (Alexakis and Tsakiris, 2010). The quality of water is mainly controlled by geological structure and mineralogy of the ecosystem, the chemical reactions that take place within the ecosystem as well as 
the type of land uses and anthropogenic activities (Alexakis, 2008). Furthermore, since water resources management has become increasingly important for sustainable development, it is necessary to assess the suitability of drainage water for agricultural use. According to Oster \& Grattan (2002) and Rhoades et al. (1992), irrigation with drainage water is necessary in parts of the world with limited supplies of appropriate water.

Groundwater is the only source of drinking and irrigation water in Siwa oasis (Abd El-Ghani, 2000 Awad et al., 1995 and Abd El-Rahman, 2001). Abd ElRahman (2001), Abd El- Samie (2000) and Shatanawi (1991) reported that two main aquifers are present in Siwa; the upper aquifer (Miocene formation) and the lower aquifer (Nubian sand stones). The upper aquifer is tapped through 226 natural springs spreading all over the depression with moderate to high salinity (TDS=1600-8000ppm) and the lower aquifer (about $600 \mathrm{~m}$ deep) is taped with 150 wells of a good water quality (TDS $=300$ to $700 \mathrm{ppm}$ ). Traditional surface irrigation systems are applied in Siwa oasis and they center around springs. Each spring serves a group of farms which is called hattyah (Aly, 2007, Abd ElRahman, 2001 and Balba, 1992). The area of the hattyah varies from 1 to more than 100 feddan according to the spring's discharge. The hattyah is surrounded by an interceptor open ditch which acts as surface and subsurface drain where surface drainage includes runoff and tail end losses. In the new developed areas, where the size of the farm depends on the discharge of the dug shallow well, water and irrigation are managed by the farmers. Some of these wells are kept free flowing causing drainage problems, therefore, individual farmers were urged to install control valves and build night storage reservoirs (Aly, 2007).

Because Siwa is a closed basin without any outlet for excess irrigation or seepage water and the presence of impermeable layer 4-10 m deep, accumulated drainage water raises the water table to $50-150 \mathrm{~cm}$ from the soil surface and causes water-logging (Schakschouk, 2002). The drainage problem started to be effective as the irrigated areas increased. Major changes in the land cover using satellite images of Siwa oasis were conducted by Aly (2007). Results indicated an increase of the vegetation surface area was from 5\% in 1973 image to $11.7 \%$ in 2005 image, a decrease in the uncultivated and Sabkha soils from $76.7 \%$ in 1973 image to $25.3 \%$ in 2005 image, the increase in the pure salt crust surface area from $0.1 \%$ in 1973 image to $27.7 \%$ in 2005 image and the increase in the lakes surface area from $18.2 \%$ in 1973 image to $35.2 \%$ in 2005 image with an increase of about $17 \%$. It was also observed that there are temporal changes and that water table depth is deteriorating over time and a wide range of water table salinity in the oasis evident. The objectives of this study were to assess the quality of drainage water in Siwa oasis and to address the suitability of its reuse to serve the sustainable management of water resources in the oasis.

\section{Materials and Methods}

Siwa Oasis is located northwestern the Egyptian Western Desert between $29^{\circ}$ $\mathrm{N}$ and $30^{\circ} \mathrm{N}$ and $25^{\circ} \mathrm{E}$ and $26^{\circ} \mathrm{E}$ and covering an area of $7333 \mathrm{~km}^{2}$. The Egypt. J. Soil. Sci. 55, No. 4 (2015) 
dominant climatic condition is the arid to semiarid conditions with very low rainfall of average $9.6 \mathrm{~mm} / \mathrm{y}$. The area has high evaporative conditions with a minimum of $4.2 \mathrm{~mm} / \mathrm{d}$ in December and a maximum of $13 \mathrm{~mm} \mathrm{~d}^{-1}$ in July. The average minimum temperature recorded was $15{ }^{\circ} \mathrm{C}$ in winter and maximum of 38 ${ }^{\circ} \mathrm{C}$ in summer (Abou El-Magd and Faid, 2007).

\section{Drainage water sampling}

GPS-referenced drainage water samples were collected in March, 2012 from all irrigated areas in Siwa Oasis. A Garmin 12XL GPS (Garmin Co., 1997) was used to locate the sampling locations, using the UTM northing - easting coordinate systems. The Landsat Image of Octorber $4^{\text {th }}$, 2013 (Google Earth, 2013) was used to allocate the collected drainage water samples (Fig.1). A number of 182 drains of different degrees were sampled in this study. At each sampling location (Table 1), the drain was divided into three segments at which a $500 \mathrm{ml}$ water samples were collected and stored frozen for further analysis and the depth of drain was also measured $(D, \mathrm{~m})$. The average of measurements of the three segments of each drain was calculated to represent the corresponding drain. The percent frequency distribution of the drains' depths is shown in Fig. 2, which indicates that the sampled drains represented all categories of drains (main, submain, branches and collectors).

TABLE 1. Names of areas from which drainage water samples were collected in Siwa Oasis.

\begin{tabular}{|c|c|c|c|c|c|}
\hline No. & Name & No. & Name & No. & Name \\
\hline 1 & Abou Bakr Al-Sedik & 16 & East Siwa & 31 & Maraqi \\
\hline 2 & Abou Eshak & 17 & Ein Alhadadeen & 32 & Tabah Noukh \\
\hline 3 & Adli & 18 & Ein Ghelit & 33 & Taghalisa \\
\hline 4 & Aghormi & 19 & Ein Mosa & 34 & Tagzerti \\
\hline 5 & Al-Ezaah & 20 & El-Dakror & 35 & Tallou \\
\hline 6 & Al-Mowta & 21 & El-Mahata & 36 & Tamish \\
\hline 7 & Al-Nakkab & 22 & Fetnas & 37 & Tankalish \\
\hline 8 & Al-Nasrani & 23 & Ghelit & 38 & Tansarah \\
\hline 9 & Al-Salamat & 24 & Hod El-Khazan & 39 & Tazola \\
\hline 10 & Al-Tabo & 25 & Hyoun & 40 & Temfert \\
\hline 11 & Al-Zeiton & 26 & Kebras & 41 & Tghaghin \\
\hline 12 & Amoun temple & 27 & Khemist & 42 & Wazidi \\
\hline 13 & Bahey Eldeen & 28 & Khenis & 43 & West Siwa \\
\hline 14 & Baston & 29 & Kleopatr & 44 & Zaamori \\
\hline 15 & Central Siwa & 30 & Mamo & 45 & Zalkkwah \\
\hline
\end{tabular}



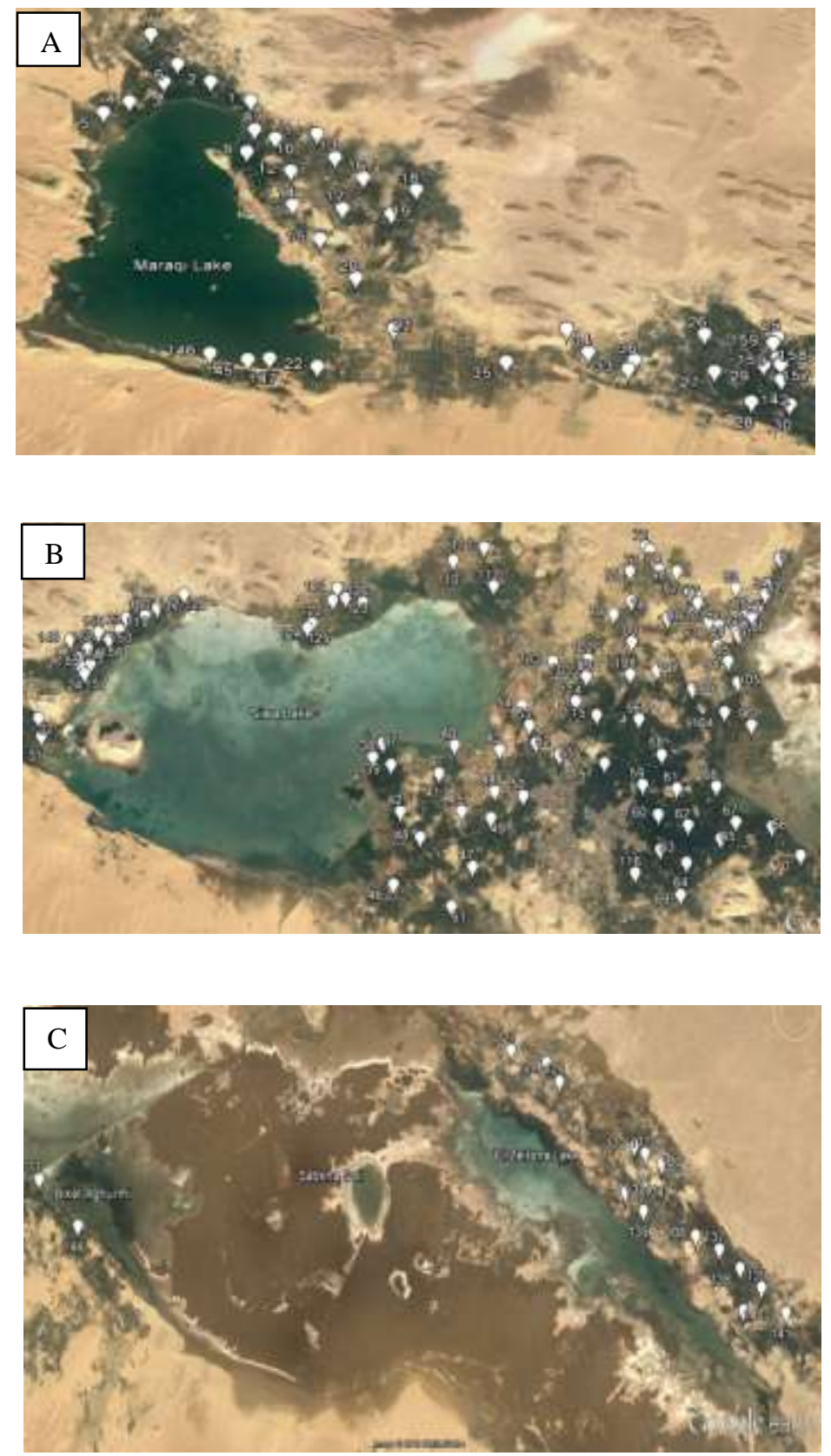

Fig. 1. Landsat image and GPS-referenced drain water samples from A) East, B) Centre and C) West of Siwa Oasis.

Egypt. J. Soil. Sci. 55, No. 4 (2015) 


\section{Laboratory analysis of drainage water samples}

Collected drainage water samples were brought to the laboratory for analysis according to the standard procedures recommended by Ayers \& Westcot (1985) and Page et al. (1982). The $\mathrm{pH}$ was measured by using $\mathrm{pH}$-meter (Jenco Electronics. LTD, Model 6071), EC by using Electrical Baxter digital conductivity meter, soluble $\mathrm{Na}$ by using Flame Photometer (Corning 400), soluble $\mathrm{Ca}^{2+}$ and $\mathrm{Mg}^{2+}$ ions using Compleximetric EDTA titration method (Lanyon and Heald, 1982) and $\mathrm{Cl}^{-}$ions by using the chromate precipitation method (Klute, 1986). The sodium adsorption ratio (SAR) and the residual soil carbonate (RSC) were calculated according to Ayers and Westcot (1985). Nitrate was measured by the UV-absorbance method described by Yang et al. (1998).

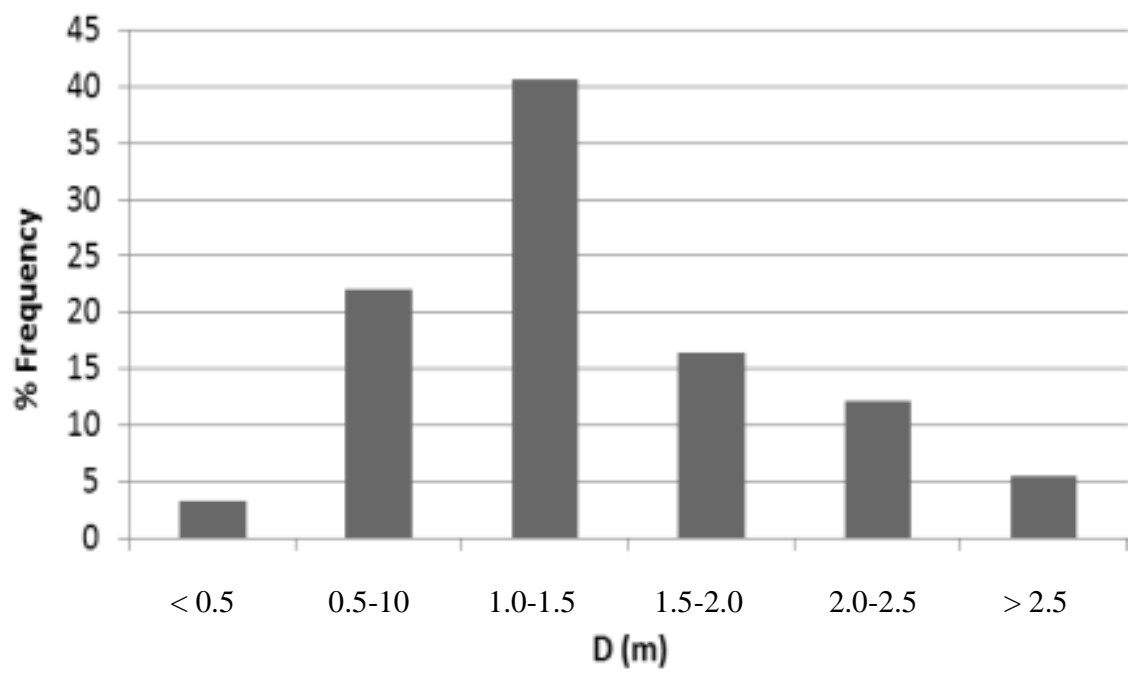

Fig. 2. Percent frequency of drains' depths sampled in Siwa Oasis.

\section{Statistical analysis}

Descriptive statistics (minimum, maximum, range, average and standard deviation) and frequency analysis were performed on the obtained data of water analysis using CoStat Software Packages (Costat, 2004).

\section{Estimation of average drainage water salinity}

The depth of drainage water $(H, \mathrm{~m})$ and the width $(W, \mathrm{~m})$ of the wetted area of each drain were measured. The wetted area was calculated $\left(A_{W}=H W, \mathrm{~m}^{2}\right)$, assuming a rectangular wetted area. The length of the drain was also measured $(L, \mathrm{~m})$ and an estimate of the drainage water volume $\left(\mathrm{V}_{\mathrm{DW}}, \mathrm{m}^{3}\right)$ found in each drain was calculated as the product of the wetted area of the drain and its length ( $V_{D W}=A_{W} L$ ). The overall average of the measured parameters in each individual drainage water sample $\left(X_{\text {avg }}\right)$ was then calculated as a drainage water volume weighted average as follows; 
where $i:$ the $i^{\text {th }}$ sampled drain,

$$
X_{\text {avg }}=\frac{\sum_{i=1}^{n}\left(X_{i} V_{D W_{i}}\right)}{\sum_{i=1}^{n} V_{D W_{i}}}
$$

$n: \quad$ the total number of sampled drains $(n=182)$,

$X_{i}$ : the individual parameter value of a water sample of the $i^{\text {th }}$ drain,

$V_{D W i}$ : the calculated volume of drainage water in the $i^{\text {th }}$ drain.

The overall averages of the measured parameters $\left(\mathrm{pH}_{\mathrm{avg}}, \mathrm{EC}_{\mathrm{avg}}, \mathrm{SAR}_{\mathrm{avg}}\right.$ $\mathrm{RSC}_{\mathrm{avg}}$, and $\mathrm{NO}_{3}-\mathrm{N}_{\mathrm{avg}}$ ) were accordingly calculated.

\section{Classification of drainage water}

Chemical data of the water samples were also presented by plotting them on a Piper-tri-linear diagram (Fig. 6). The software code GW-Chart (Winston, 2000) was employed for the Piper tri-linear diagrams.

Data of the collected drainage water samples were divided into three groups corresponding to the west, middle and east parts of the oasis. In addition, the overall averages of the chemical analysis data were presented on the Piper diagram.

\section{Results and Discussion}

Descriptive statistics of the measured parameters are listed in Table 2. Frequency distributions of the measured water quality parameters are also presented in Fig. 3 and 4. The measured pH ranged between 6.82 and 8.03 and was found to be within the normal range of natural waters (Ayers and Westcot, 1985). As shown in Fig. 3, very few samples had pH values less than 7 (1.65\%) or higher than $8(0.5 \%)$. Therefore, the majority of samples recorded $\mathrm{pH}$ values between 7 and 8 with 7.54 as a mean value. The EC ranged from 2.78 to 62.90 $\mathrm{dS} / \mathrm{m}$ with a mean value of $13.70 \mathrm{dS} / \mathrm{m}$, while few samples $(2.2 \%)$ recorded EC values less than $4 \mathrm{dS} / \mathrm{m}$, about $25.83 \%$ had EC values ranged from 16 to <32 $\mathrm{dS} / \mathrm{m}$ (Fig. 3). The majority of samples (71.97\%) had EC values ranged from 4 to16 $\mathrm{dS} / \mathrm{m}$ (Table 2). RSC ranged from 0.53 to 2.69 with a mean value of 1.89 (Fig. 3). Only $6.59 \%$ of the tested samples had RSC values $<1.25$, while $28.57 \%$ had RSC higher than 2.25 .

TABLE 2. Descriptive statistics of different criteria of Siwa Oasis drainage water.

\begin{tabular}{|lccccccc|}
\hline Criteria & $\mathbf{p H}$ & $\begin{array}{c}\mathbf{E C} \\
(\mathbf{d S} / \mathbf{m})\end{array}$ & $\mathbf{R S C}$ & $\begin{array}{c}\mathbf{N a}^{+} \\
(\mathbf{m e q} / \mathbf{l})\end{array}$ & $\begin{array}{c}\mathbf{C l}^{-} \\
(\mathbf{m e q} / \mathbf{l})\end{array}$ & $\mathbf{S A R}$ & $\begin{array}{c}\mathbf{N O}^{-} \mathbf{- N} \\
(\mathbf{m g} / \mathbf{l})\end{array}$ \\
\hline Minimum & 6.82 & 2.78 & 0.53 & 24.96 & 23.97 & 4.56 & 5.25 \\
Maximum & 8.03 & 62.90 & 2.69 & 987.21 & 947.73 & 78.15 & 42.51 \\
Mean & 7.54 & 13.70 & 1.89 & 204.07 & 195.91 & 27.15 & 14.56 \\
Range & 1.21 & 60.12 & 2.16 & 962.25 & 923.76 & 73.59 & 42.51 \\
SD & 0.26 & 8.87 & 0.44 & 149.58 & 143.60 & 12.48 & 6.31 \\
\hline
\end{tabular}

Egypt. J. Soil. Sci. 55, No. 4 (2015) 

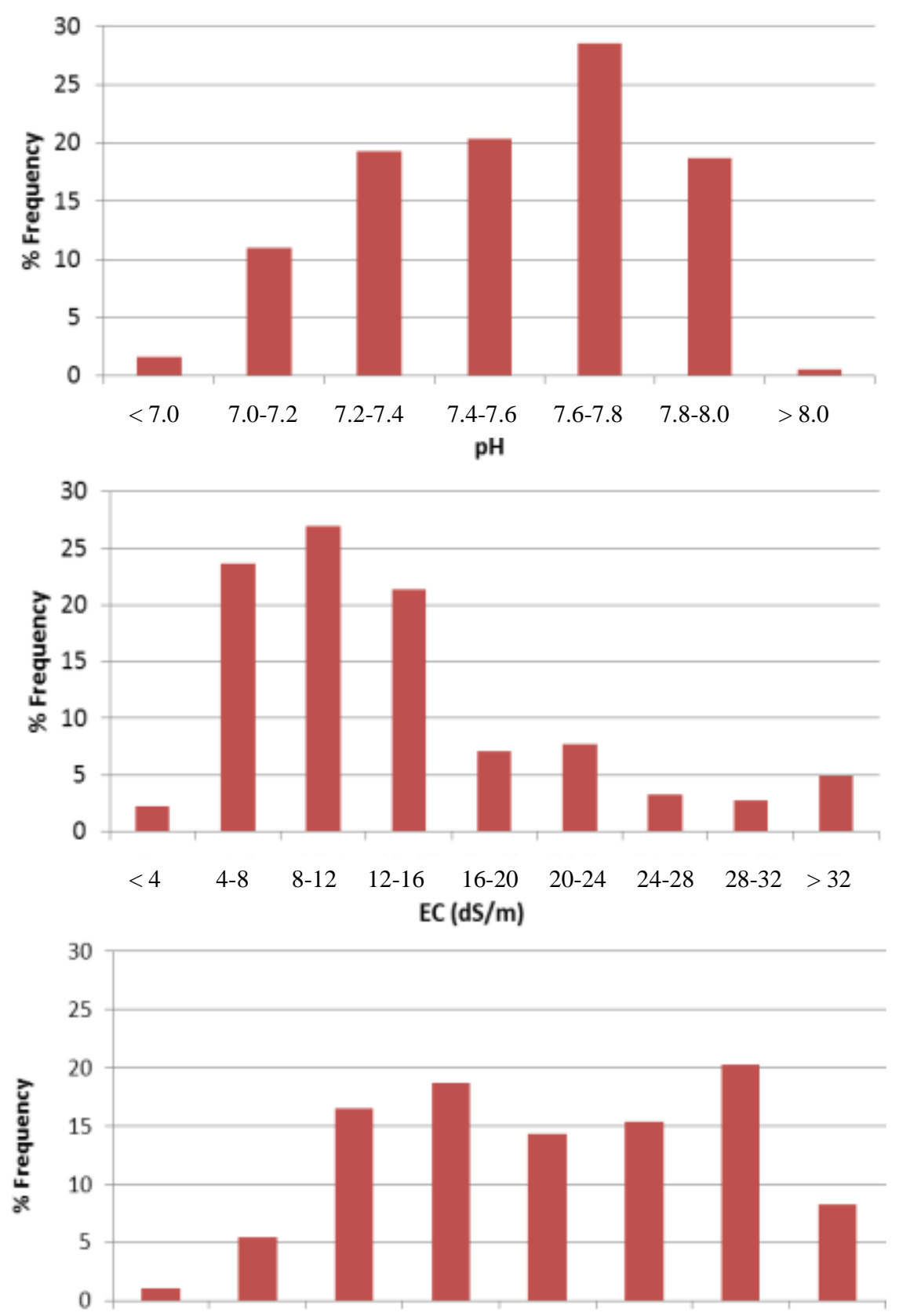

$<1.00 \quad 100-1.25 \quad 1.25-1.5 \quad 1.5-1.75 \quad 1.75-2.00 \quad 2.00-2.25 \quad 2.25-2.50>2.50$ RSC

Fig. 3. Percent frequency of EC, $\mathrm{pH}$ and $\mathrm{RSC}$ in drainage water from Siwa oasis.

Egypt. J. Soil. Sci. 55, No. 4 (2015) 

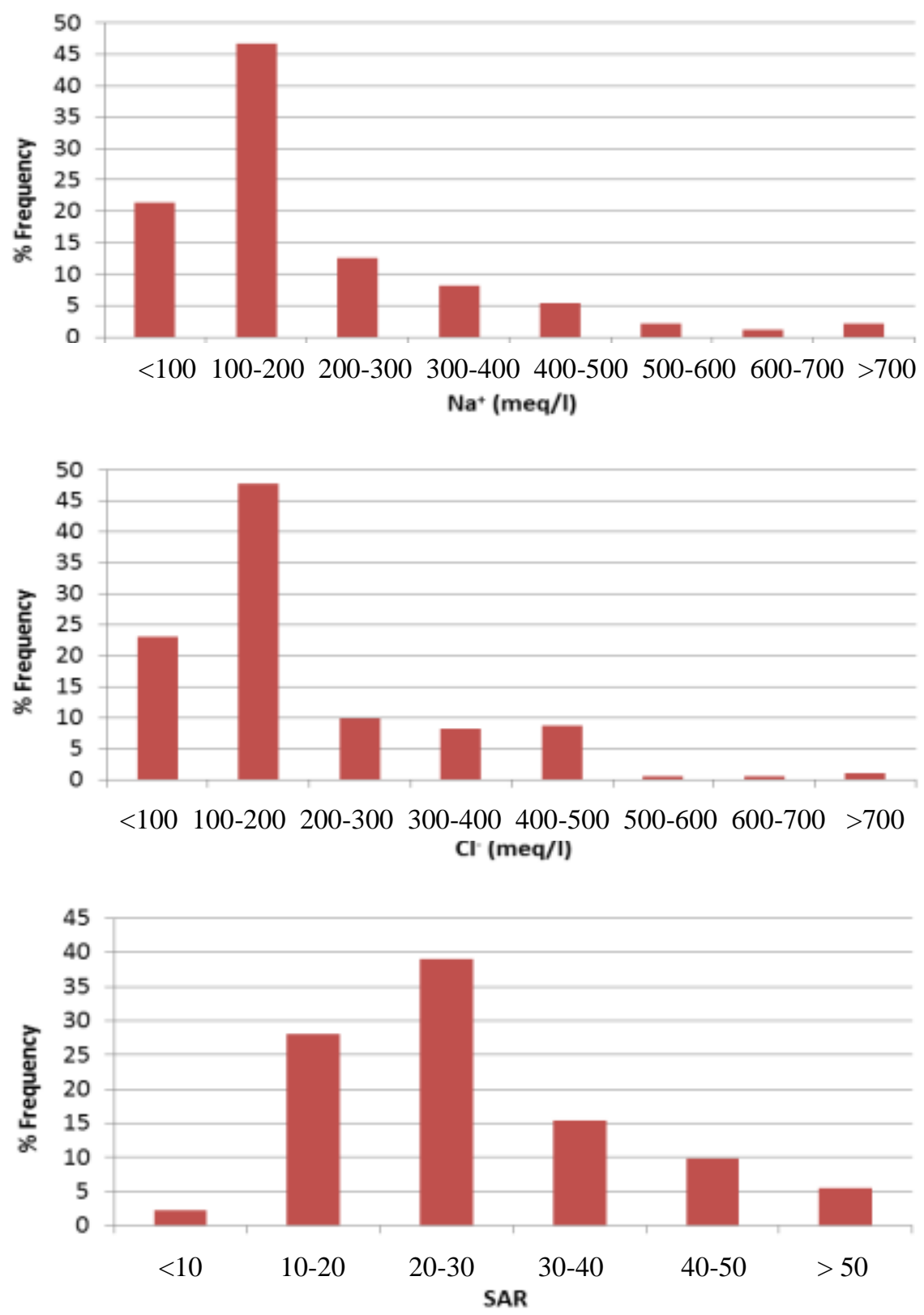

Fig. 4. Percent frequency of $\mathrm{Na}^{+}$and $\mathrm{Cl}^{-}$ion concentrations and $\mathrm{SAR}$ in drainage water from Siwa oasis.

Egypt. J. Soil. Sci. 55, No. 4 (2015) 
The concentrations of $\mathrm{Na}^{+}$and $\mathrm{Cl}^{-}$ions ranged from 24.96 to 987.21 and from 23.97 to $947.73 \mathrm{meq} / \mathrm{l}$ and with mean values recorded 204.07 and $195.91 \mathrm{meq} / \mathrm{l}$, respectively. Since both $\mathrm{Na}^{+}$and $\mathrm{Cl}^{-}$ions constituted more than $85 \%$ of the soluble ions in the tested samples (Table 2), high correlation coefficients of 0.961 and 0.957 were found between these two ions and the EC, respectively. Also, a correlation coefficient of 0.931 was found between the measured concentrations of both ions and they took alike in their frequency distributions (Fig. 4). Only $5.5 \%$ and $3.2 \%$ of the collected samples recorded $\mathrm{Na}$ and $\mathrm{Cl}$ concentrations > $5000 \mathrm{meq} / \mathrm{l}$, respectively while $68.13 \%$ and $60.88 \%$ of collected samples recorded $<200 \mathrm{meq} / \mathrm{l}$ of $\mathrm{Na}^{+}$and $\mathrm{Cl}^{-}$ion concentrations, respectively.

Calculated SAR values ranged from 4.56 to 78.15 with a mean value of 27.15 (Table 2). Only 2.2 and $5.49 \%$ of the collected samples (Fig. 4) recorded extreme SAR values $<10$ and $>50$, respectively. On the other hand, $39.01 \%$ of the collected samples had SAR values between 20 and 30 as the highest percent frequency among samples.

Nitrate concentrations in the drainage water ranged from 5.25 to $42.51 \mathrm{mg} / \mathrm{l}$ with a mean value of $14.56 \mathrm{mg} / \mathrm{l}$ (Table 2 ). Only $4.40 \%$ of the collected samples recorded nitrate concentrations $>40 \mathrm{mg} / \mathrm{l}$ while more than $50 \%$ recorded nitrate concentrations $<10 \mathrm{mg} / \mathrm{l}$ (Fig. 5).

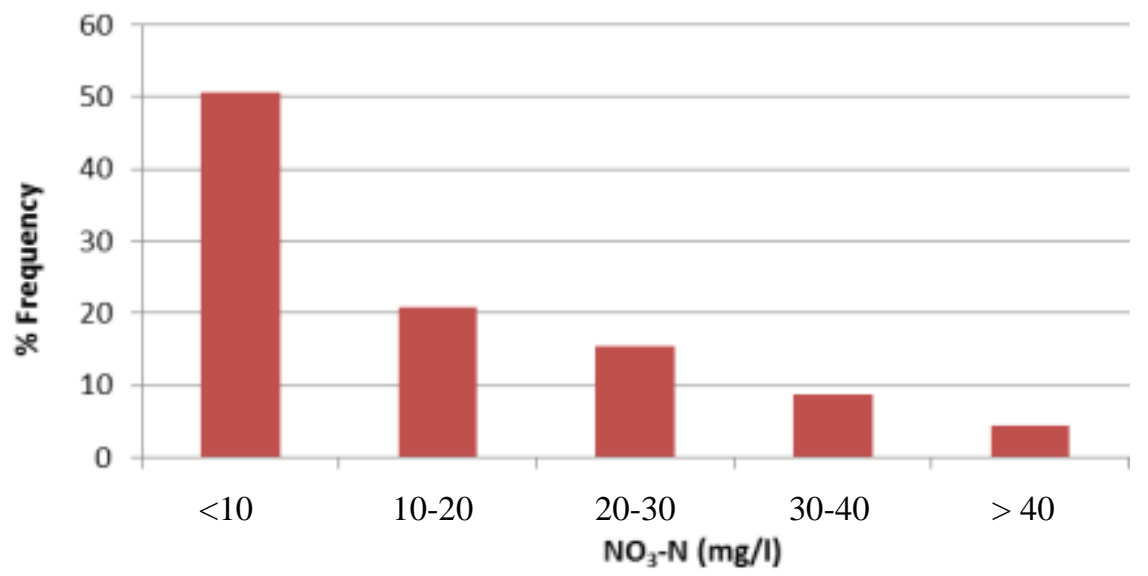

Fig. 5. Percent frequency of nitrate concentration in drainage water from Siwa oasis.

The calculation of the overall averages of the measured parameters of the drainage water is presented in Table 3. The volume of drainage water in each sampled area was calculated from which the total drainage water volume $\left(\sum V_{D W i}\right)$ of all sampled areas was calculated $\left(49695 \mathrm{~m}^{3}\right)$. The calculated volume weighted averages of the drainage water parameters $\mathrm{pH}_{\mathrm{avg}}, \mathrm{EC}_{\mathrm{avg}}, \mathrm{SAR}_{\mathrm{avg}}, \mathrm{RSC}_{\mathrm{avg}}$, and $\mathrm{NO}_{3}-\mathrm{N}_{\text {avg }}$ were $8.85 \mathrm{dS} / \mathrm{m}, 7.46,21.19,1.72$ and $13.51 \mathrm{mg} / \mathrm{l}$, respectively. These values were found to be generally higher than those mathematical mean values calculated previously (Table 2). The volume weighted averages are assumed to represent the condition where drainage water would be collected and mixed for 
reuse purposes in the oasis. According to Ayers and Westcot (1985), the salinity and sodicity hazards of such drainage water can be classified as C3S4, i.e. high salinity and very high sodicity hazards.

TABLE 3. Calculation of volume weighted averages of drainage water quality criteria.

\begin{tabular}{|c|c|c|c|c|c|}
\hline \multirow{2}{*}{ Sum/Average } & \multicolumn{5}{|c|}{ Criteria } \\
\hline & EC & pH & SAR & RSC & $\mathrm{NO}_{3}-\mathrm{N}$ \\
\hline$\sum X_{i} V_{D W i}^{a}$ & 439818 & 370722 & 1053268 & 85400 & 671564 \\
\hline$X_{\text {iavg }}^{b}$ & 8.85 & 7.46 & 21.19 & 1.72 & 13.51 \\
\hline
\end{tabular}

${ }^{\mathrm{a}} X_{i}$ refers to individual measured drainage water criteria; EC, $\mathrm{pH}, \mathrm{SAR}, \mathrm{RSC}$ or $\mathrm{NO}_{3}-\mathrm{N}$.

${ }^{\mathrm{b}}$ The calculated total volume of sampled drainage water was $49695 \mathrm{~m}^{3}$.

Piper diagram provides a convenient method to classify and compare water types based on the ionic composition of different water samples. Tri-linear plots are used in hydrogeological studies as an effective graphical means of displaying data that contain three dominant components, each of which is typically expressed as a percentage of the total of the three (Alexakis et al., 2011). For example, analyses of water samples can be plotted on a tri-linear plot to show relative percentages of three cations $\left(e . g ., \mathrm{Na}^{+}+\mathrm{K}^{+}, \mathrm{Ca}^{+2}\right.$, and $\left.\mathrm{Mg}^{+2}\right)$, anions (e.g. $\left.\mathrm{Cl}^{-}, \mathrm{SO}_{4}^{-2}, \mathrm{CO}_{3}^{-2}\right)$. The point in the diamond shaped field represents the overall chemical character of the water sample. This point is plotted as the point of intersection of the rays projected from the anion and cation triangular fields into the diamond field. The plotted results points on the diamond plot in Fig. 6 revealed the dominance of $\mathrm{Cl}^{-}+\mathrm{SO}_{4}^{-2}$ anions and $\mathrm{Na}^{+}+\mathrm{K}^{+}$cations in the drainage water of the oasis if they would eventually be mixed.

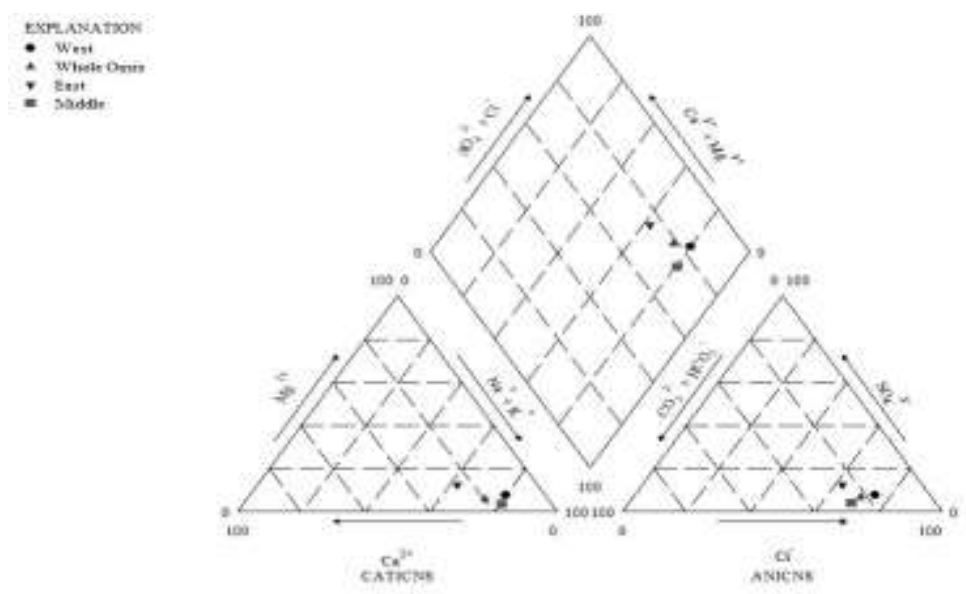

Fig. 6. Piper-tri-linear diagram depicting hydrochemical facies of the drainage water samples from Siwa Oasis.

Egypt. J. Soil. Sci. 55, No. 4 (2015) 
These results are in agreement with those obtained by Masoud and Koike (2006) and Aly (2007) who confirmed an acceleration in the rate of soil salinization and vegetation death after the year 2000. Further, this was found to be related to the relative climate warming and the over-irrigation accompanied with improper drainage systems set up as well as the absence of an effective water resource management plan. These conditions resulted in the development of water runoff and seepage to low lying land, salinity and water logging in many lands of the oasis.

Since the oasis is an isolated ecosystem, unconventional recommendations, measures and interventions that may prevent or ameliorate the exacerbation of these drainage problems (Rhoades et al., 1992). This may include the following:

1- Control of new well drilling and tapping of the existing well.

2- Lining of well outflow basins and irrigation canals to reduce drainage water volumes and water logging.

3- Use of low-salinity natural flowing springs to irrigate winter crops such as cereals and forage.

4- Use of saline water over $5 \mathrm{dS} / \mathrm{m}$ to irrigate salt tolerant crops like barley, vetches, Rhodes grass, sugar beet, etc.

5- Use of biologically-active drainage water for the production of windbreak and growing wood trees.

6- Use of drainage water for stabilization of sand dunes.

7- Reuse of drainage water after blending with good quality water (recently drilled deep well of salinity EC $\approx 0.5 \mathrm{dS} / \mathrm{m}$ with SAR of 5 ) or by alternating the drainage water with good quality water.

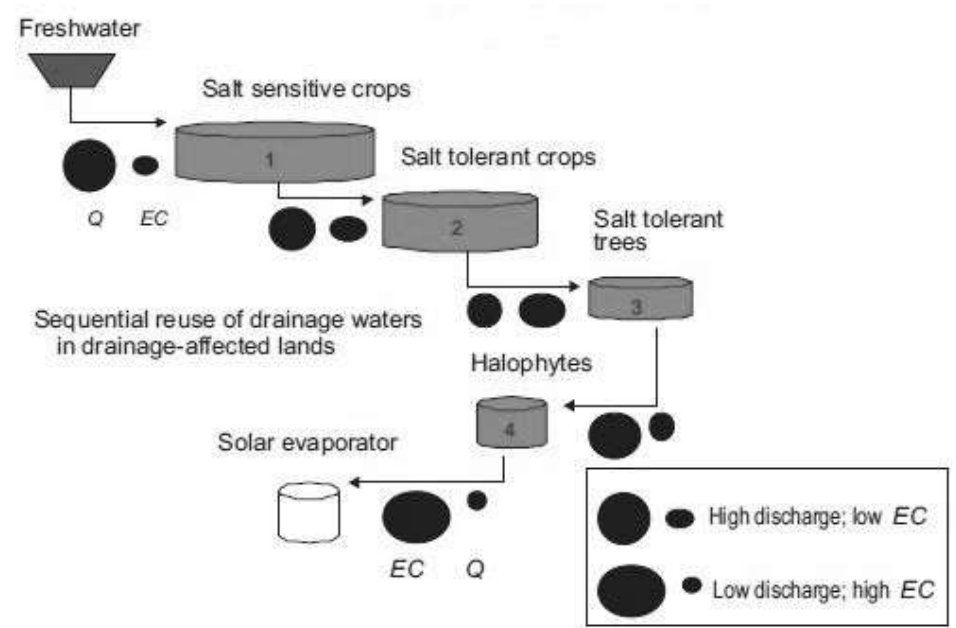

Fig. 7. Illustration of an integrated on-farm drainage management (IFDM) system (adapted from Tanji and Kielen, 2002). 
8- Adoption of an integrated on-farm drainage management (IFDM) systems (Tanji \& Kielen, 2002 and Oster \& Grattan, 2002) where good quality irrigation water is used for salt sensitive and moderately sensitive crops and water drainage from these crops is collected to be used to irrigate moderately salt tolerant crops from which drainage water can be directed to fields cultivated with salt tolerant or halophytes (Fig. 7).

9- Increase the public awareness to this problem and give the chance to the NGO's contribution.

\section{Conclusion}

The hydrochemical analyses were performed on drainage water samples of Siwa oasis collected from all drainage categories. The volume weighted averages were assumed to represent the condition where drainage water would be collected and mixed for reuse purposes in the oasis. Results showed that drainage water was corresponded mainly to $\mathrm{Na}-\mathrm{Cl}-\mathrm{SO}_{4}$ type imposing moderate to high salt and high sodicity hazards. Nitrate concentration was found to have no possible impacts on the environment. Unconventional interventions that may prevent or ameliorate the exacerbation of the drainage problems including groundwater pumping control, IFDM approach and increase the public awareness to this problem.

Acknowledgement: The author greatly appreciates the financial support of this study by the research project on the integrated approach of sustainable development of Siwa Oasis ecosystem, funded by the Ministry of Agriculture, Egypt.

\section{References}

Abd El-Ghani, M.M. (2000) Vegetation composition of Egyptian inland salt marshes. Bot. Bull. Acad. Sim. 41, 305-314.

Abd El-Rahman, A. (2001) Spatiotemporal monitoring and assessment of water resources in Siwa oasis. M.Sc. Thesis, Fac. of Agric., Alex. Univ., Egypt.

Abd El-Samie, M.K. (2000) Classification and evaluation of Siwa Oasis soils. Ph.D Thesis, Fac. of Agric. Ain Shams University, Egypt.

Abou El-Magd, I. and Faid, A. (2007) Hydrogeological and environmental studies on Siwa oasis, Egypt Using GIS technique. Egypt. J. Soil Sci. 47, 435-450.

Alexakis, D. (2008) Geochemistry of stream sediments as a tool for assessing contamination by Arsenic, Chromium and other toxic elements: East Attica region, Greece. European Water, 21, 57-72.

Alexakis, D., Gotsis, D. and Giakoumakis, S. (2011) Assessment of drainage water quality in pre and post-irrigation seasons for supplemental irrigation use. Environ. Monit. Assess. DOI 10.1007/s10661-11-2321-2.

Egypt. J. Soil. Sci. 55, No. 4 (2015) 
Alexakis, D. and Tsakiris, G. (2010) Drought impacts on karstic spring annual water potential. Application on Almyros (Heraklion Crete) brackish spring. Desalination and Water Treatment, 16, 1-9. doi:10.5004/dwt. 2010.1065.

Aly, A.A. (2007) A holistic ecosystem approach for sustainable management of land and water resources in Siwa oasis. Ph.D. Thesis, Faculty of Agric., Univ. Alexandria, Egypt.

Awad, M. A., Abdel Baki, A. A. and Hamza, M. S. (1995) Isotope hydrology and geochemistry of water resources of Siwa Oasis, Western Desert, Egypt. Extended Synopses, Inter. Symposium on Isotopes in Water Resources Management. Austria ( IAEA-SM-336/11p), pp.112.116.

Ayers, R.S. and Westcot, D.W. (1985) Water quality for agriculture. FAO Irrigation and Drainage Paper No. 29 (Rev. 1). Rome.

Balba, A.M. (1992) Agricultural development activities in the western desert in Egypt. Sahara Review. 6, 35-79.

Cost (2004) CoStat: Statistical Analysis Package Ver. 6.303. CoHort Software. CA, USA.

Garmin Co. (1997) Owner's manual and references. Olathe, KS, USA.

Google Earth (2013) Image Landsat 4/10/2013. Data SIO, NOAA, U.S. Navy, NGA, GEBCO. Google Inc.

Klute, A. (1986) Methods of Soil Analysis. Part 1. $2^{\text {nd }} e d$. Agron. Monorgraph No. 9. ASA and SSSA, Madison, WI.

Lanyon, L.E. and Heald, W.R. (1982) Magnesium, Calcium, Strontium, and Barium. In A.L. Page et al. (Ed.). Methods of Soil Analysis, Part 2. Chemical and Microbiological Properties. Agron. Monograph No. 9 ( $2^{\text {nd }}$ edition) ASA-SSSA, Madisen, WI.

Masoud, A.A. and Koike, K. (2006) Arid land salinization detected by remotely-sensed landcover changes: A case study in the Siwa region, NW Egypt. J. Arid Environ. 66, 151-167.

Oster, J.D. and Grattan, S.R. (2002) Drainage water reuse. Irrig. and Drainage Syst. $16: 297-310$

Page, A.L., Miller, R.H. and Keeney, D.R. (1982) Methods of Soil Analysis. Part II. 2nd ed. Agron. Monogr. 9 Madison, Wisconsin, USA.

Rhoades, J.D., Kandiah, A. and Mashali, A.M. (1992) The use of saline waters for crop production. Irrigation and Drainage Paper 48. FAO, Rome, pp.

Shatanawi, M.R. (1991) Irrigation development and management in Siwa Oasis, Egypt. Report No.6.

Tanji, K.K. and Kielen, N.C. (2002) Agricultural drainage water management in arid and semi-arid areas. FAO Irrigation and Drainage Paper No. 61. Rome. 
Schakschouk, A.M. (2002) Drainage water reuse to control water table in Siwa Oasis. Alex. Sci. Exch. 23, 121-156.

Winston, R.B. (2000) Graphical User Interface for MODFLOW, Version 4: U.S. Geological Survey Open-File Report 00-315, 27 p.

Yang, J.E., Skogley, E.O., Schaff, B.E. and Kim, J.J. (1998) A simple spectrophotometric determination of nitrate in water. Soil Sci. Soc. Am. J. 62, 1108-1115.

(Received 24/12/2014;

accepted 30/12/2015)

Egypt. J. Soil. Sci. 55, No. 4 (2015) 


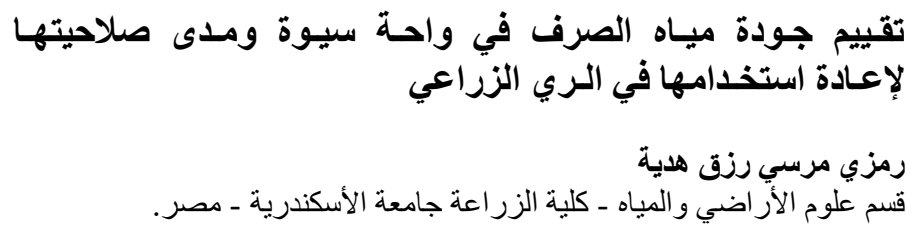

إن إعادة استخدام مياه الصرف في الزراعة تعتبر من أكثر التحديات التي تواجهنا

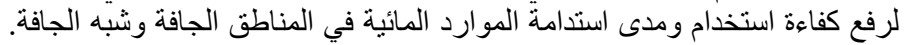

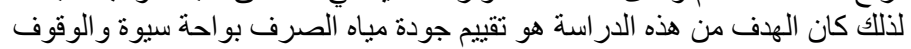

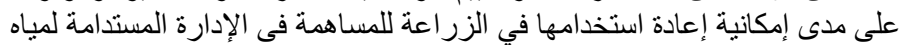

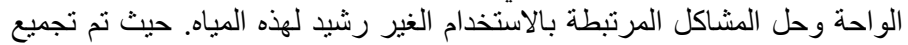

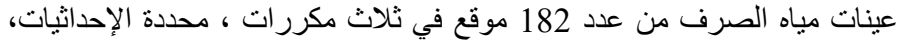

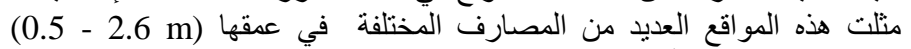

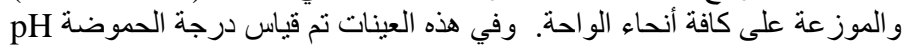
و التوصيل الكهربي EC

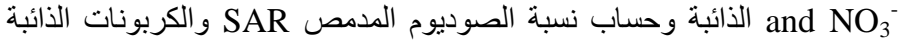

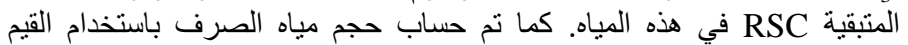

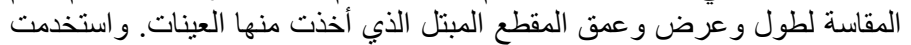

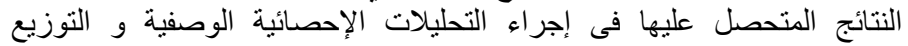

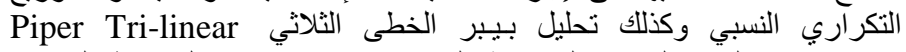
Analyses pH 8.85 dS/m, 7.46, حيث وجدت تساوي SAR avg, RSC التون 21.19, 1.72 and 13.51 mg/l

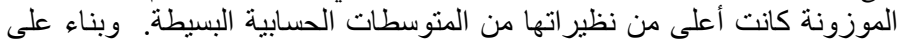
كل من قيم EC

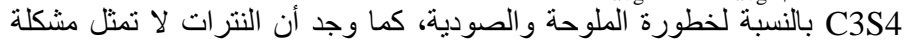

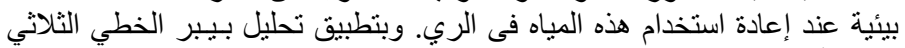

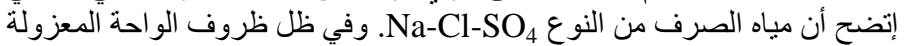

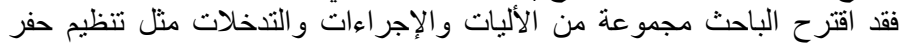

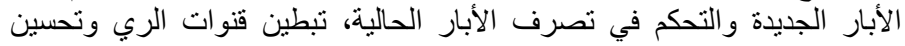

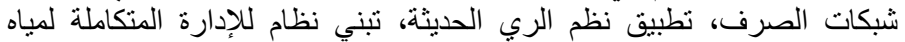

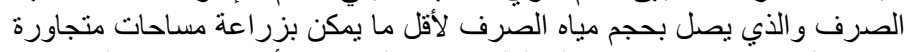

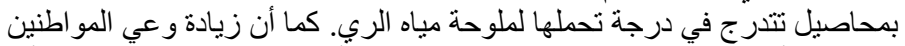

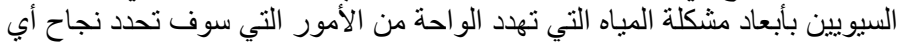
جهد يمكن بذله في هذا المجال. 